\title{
HUBUNGAN DIAGNOSA KEPERAWATAN DALAM PENERAPAN ASUHAN KEPERAWATAN TERHADAP KEPUASAN PASIEN
}

\author{
Januarizkah Napitu \\ januarizkahnapitu@gmail.com
}

\section{LATAR BELAKANG}

Rumah sakit sebagai jasa pemberi layanan kesehatan harus mampu memberikan rasa puas kepada para pengguna layanan, sehingga pengguna layanan mendapatkan kepuasan. Kepuasan pasien merupakan salah satu indikator keberhasilan pemberian pelayanan kesehatan kepada masyarakat. Pasien yang puas dapat menjadi aset berharga bagi Rumah Sakit karena akan terus memakai jasa layanan kesehatan Rumah sakit pilihannya. Penurunan jumlah pasien merupakan salah satu indikasi dari ketidakpuasan pasien pada pelayanan puskesmas walaupun tidak signifikan dalam membuktikan kepuasan atau ketidakpuasan pasien. Kepuasan pasien akan terpenuhi bila pelayanan yang diberikan telah sesuai dengan harapan mereka. Apabila pelayanan yang diberikan belum sesuai dengan harapan pasien maka pasien akan merasa tidak puas.

Perawat adalah salah satu tenaga kesehatan yang memegang peranan penting dalam pelayanan kesehatan dirumah sakit. Perawat memiliki peran memberikan asuhan keperawatan yang berkualitas karena perawat berinteraksi langsung selama 24 jam dengan pasien. Mutu asuhan keperawatan sangat dipengaruhi oleh kualitas pelayanan kesehatan dan Perawat harus mampu memberikan pelayanan keperawatan yang optimal sesuai standar pelayanan keperawatan yang telah ada. Hal tersebut dikarenakan kepuasan pasien merupakan indikator keberhasilan pelayanan keperawatan.

Profesi perawat menggunakan proses keperawatan (nursing process) sebagai kerangka pikir dan kerangka kerja dalam merawat pasien. Keperawatan sebagai proses, diperkenalkan sejak tahun 1955 oleh Hall dan pada tahun 2004 proses keperawatan (nursing process) ditetapkan sebagai series of steps oleh ANA (American Nursing Association) (Wilkinson, 2007), yang terdiri dari assesment (pengkajian), diagnosis (penetapan diagnosis), planning outcomes (perencanaan hasil), planning intervention (perencanaan intervensi), implementation (implementasi) dan evaluation (evaluasi). 
Karena pengertian dari Diagnosa keperawatan adalah keputusan klinik tentang respon individu, keluarga, dan masyarakat tentang masalah kesehatan aktual atau potensial, sebagai dasar seleksi intervensi keperawatan untuk mencapai tujuan asuhan keperawatan sesuai dengan kewenangan perawat, disini saya ingin mencari tahu hubungan diagnosa keperawatan dalam asuhan keperawatan terhadap kepuasan pasien.

\section{METODE}

Metode yang saya gunakan dalam membuat artikel ini disebut literasi. Saya membaca beberapa informasi dari berbagai sumber referensi berupa buku, dan jurnal. Melalui metode inilah saya memahami dan mengidentifikasi diagnosa keperawatan, tujuan diagnosa keperawatan, komponen diagnosa keperawatan, bagaimana dalam merumuskan diagnosa keperawatan, dan mengetahui seberapa pentingnya kepuasan pasien dalam asuhan keperawatan, serta hubungan diagnosa keperawatan terhadap kepuasan pasien.

\section{HASIL}

Perawat adalah salah satu tenaga kesehatan yang memegang peranan penting dalam pelayanan kesehatan dirumah sakit. Perawat memiliki peran memberikan asuhan keperawatan yang berkualitas karena perawat berinteraksi langsung selama 24 jam dengan pasien, dan jumlah perawat yang mendominasi sehingga perawat harus mampu memberikan pelayanan keperawatan yang bermutu (Nursalam, 2011). Oleh karena itu pelayanan keperawatan memiliki kontribusi yang besar dalam meningkatkan mutu pelayanan rumah sakit

Proses asuhan keperawatan merupakan tugas dan kewajiban seorang perawat dari pasien datang sampai pasien pulang, dimulai dengan pengkajian secara menyeluruh, kemudian menegakkan diagnosa keperawatan dari data pengkajian tersebut, serta melaksanakan intervensi, implementasi dan evaluasi keefektifan diagnosa awal yang sudah ditegakkan. Diagnosa keperawatan adalah keputusan klinik tentang respon individu, keluarga, dan masyarakat tentang masalah kesehatan aktual atau potensial, sebagai dasar seleksi intervensi keperawatan untuk mencapai tujuan asuhan keperawatan sesuai dengan kewenangan perawat. 
Kepuasan pasien akan terpenuhi bila pelayanan yang diberikan telah sesuai dengan harapan mereka. Apabila pelayanan yang diberikan belum sesuai dengan harapan pasien maka pasien akan merasa tidak puas. Perawat harus mampu memberikan pelayanan keperawatan yang optimal sesuai standar pelayanan keperawatan yang telah ada. Hal tersebut dikarenakan kepuasan pasien merupakan indikator keberhasilan pelayanan keperawatan. Kepuasan pasien ditunjukkan dengan adanya peningkatkan jumlah pasien yang menggunakan fasilitas jasa layanan yang diberikan oleh Rumah Sakit.

Berdasarkan literatur yang saya baca, berdasarkan penelitian dari jurnal Fatmawati Astar, Hasmin Tamsah, Ikhasan Kadir, yang berjudul "PENGARUH PELAYANAN ASUHAN KEPERAWATAN TERHADAP KEPUASAN PASIEN DI PUSKESMAS TAKALALA KABUPATEN SOPPENG” mengatakan bahwa semakin lengkap, akurat dan jelas penjelasan tentang diagnosa keperawatan maka kepuasan pasien akan semakin menurun. Hal ini disebabkan karena diagnosa keperawatan/ masalah kesehatan merupakan salah satu stressor pasien.

\section{PEMBAHASAN}

\section{A. DIAGNOSA KEPERAWATAN}

\section{1) Definisi Diagnosa Keperawatan}

Diagnosa keperawatan merupakan suatu pernyataan yang menjelaskan respon manusia (status kesehatan atau resiko perubahan pola) dari individu atau kelompok dimana perawat secara akuntabilitas dapat mengidentifikasi dan memberikan intervensi keperawatan secara pasti untuk menjaga status kesehatan, membatasi, mencegah, dan mengubahnya (Carpenito, 2000).

Gordon (1982) mendefinisikan bahwa diagnosa keperawatan adalah masalah kesehatan kesehatan aktual dan potensial dimana berdasarkan pendidikan dan pengalamannya , dia mampu dan mempunyai kewenangan untuk memberikan tindakan keperawatan. Kewenangan tersebut didasarkan pada standar praktik keperawatan dan etik keperawatan yang berlaku di Indonesia (Nursalam, 2001)

North American Nursing Diagnosis Assosiation (NANDA) menyatakan bahwa Diagnosa keperawatan adalah keputusan klinik tentang respon individu, keluarga, dan 
masyarakat tentang masalah kesehatan aktual atau potensial, sebagai dasar seleksi intervensi keperawatan untuk mencapai tujuan asuhan keperawatan sesuai dengan kewenangan perawat. Semua diagnosis harus didukung dengan data, dimana menurut NANDA diartikan sebagai definisi karakteristik. Definisi karakteristik tersebut dinamakan tanda dan gejala, tanda adalah sesuatu yang dapat di observasi dan gejala adalah sesuatu yang dirasakan oleh klien.

Diagnosa keperawatan adalah langkah kedua dari proses keperawatan yang menggambarkan penilaian klinis tentang respon individu, keluarga, kelompok maupun masyarakat terhadap permasalahan kesehatan baik aktual maupun potensial. Dimana perawat mempunyai lisensi dan kompetensi untuk mengtasinya ( Sumijatun, 2010 ). Diagnosa keperawatan adalah suatu pernyataan yang singkat, tegas, dan jelas tentang respon klien terhadap masalah kesehatan/penyakit tertentu yang aktual dan potensial karena ketidaktahuan, ketidakmauan, atau ketidakmampuan pasien/klien mengatasinya sendiri yang membutuhkan tindakan keperawatan untuk mengatasinya ( Ali, 2009 ).

Kriteria diagnosa keperawatan Kriteria antara lain sebagai berikut :

a) Status kesehatan dibandingkan dengan standar untuk menentukan kesenjangan.

b) Diagnosa keperawatan dihubungkan dengan penyebab kesenjangan dan pemenuhan kebutuhan pasien.

c) Diagnosa keperawatan dibuat sesuai dengan wewenang.

d) Komponen diagnosa terdiri atas PE/PES.

e) Pengkajian ulang dan revisi terhadap diagnosis berdasarkan data terbaru.

\section{2) Tujuan diagnosa keperawatan}

Tujuan diagnosa keperawatan untuk mengidentifikasi menurut Wahid \& Suprapto (2012) sebagai berikut:

a) Masalah dimana adanya respon klien terhadap status kesehatan atau penyakit.

b) Faktor yang menunjang atau menyebabkan suatu masalah.

c) Kemampuan klien untuk mencegah atau menyelesaikan masalah.

d) Mengkomunikasikan masalah klien pada tim kesehatan. 
e) Mendemonstrasikan tanggung jawab dalam indentifikasi masalah klien.

f) Mengidentifikasi masalah utama untuk perkembangan intervensi keperawatan.

\section{3) Komponen diagnosa keperawatan}

Komponen diagnosa keperawatan menurut Dermawan (2012) sebagai berikut:

a) Problem

Problem adalah gambaran keadaan pasien dimana tindakan keperawatan dapat diberikan. Masalah atau problem adalah kesenjangan atau penyimpangan dari keadaan normal yang seharusnya tidak terjadi. Tujuan : menjelaskan status kesehatan pasien secara jelas dan sesingkat mungkin.

Diagnosis keperawatan disusun dengan menggunakan standart yang telah disepakati, supaya :

(1) Perawat dapat berkomunikasi dengan istilah yang dimengerti secara umum.

(2) Memfasilitasi dan mengakses diagnosa keperawatan.

(3) Sebagai metode untuk mengidentifikasi perbedaan masalah keperawatan dengan masalah medis.

(4) Meningkatkan kerjasama perawat dalam mendefinisikan diagnosis dari data pengkajian dan intervensi keperawatan.

\section{b) Etiologi}

Etiologi atau faktor penyebab adalah faktor klinik dan personal yang dapat merubah status kesehatan atau mempengaruhi perkembangan masalah. Merupakan pedoman untuk merumuskan intervensi.

Unsur - unsur dalam identifikasi etiologi meliputi unsur PSMM :

(1) Patofisiologi penyakit : semua proses penyakit, akut atau kronis yang dapat menyebabkan atau mendukung masalah.

(2) Situasional : personal dan lingkungan (kurang pengetahuan, isolasi sosial). 
(3) Medikasi (berhubungan dengan program perawatan atau pengobatan) : keterbatasan institusi atau rumah sakit, sehingga tidak mampu memberikan perawatan.

(4) Maturasional : adolensent (ketergantungan dalam kelompok), young adult (menikah, hamil, menjadi orang tua), dewasa (tekanan karier).

c) Sign and symptom

Data subyektif dan obyektif yang ditemukan sebagai komponen pendukung terhadap diagnosa keperawatan. Sign and symptom (tanda dan gejala) adalah ciri, tanda atau gejala yang merupakan informasi yang diperlukan untuk merumuskan diagnosa keperawatan.

Komponen diagnosa keperawatan menurut PPNI (2010) terdiri dari masalah (P), etiologi atau penyebab (E) dan tanda atau gejala (S) atau terdiri dari masalah dengan penyebab (PE).

\section{4) Langkah - langkah menentukan diagnosa keperawatan}

Langkah - langkah menentukan diagnosa keperawatan menurut Setiadi (2012) sebagai berikut:

a) Klasifikasi dan analisis data

Klasifikasi atau memfokuskan data adalah mengelompokan data-data pasien atau keadaan tertentu dimana klien mengalami permasalahan kesehatan atau keperawatan berdasarkan kriteria permasalahannya. Analisis data adalah kemampuan mengkaitkan data dan menghubungkan data tersebut dengan konsep teori dan prinsip yang relevan untuk membuat kesimpulan dalam menentukan masalah kesehatan dan keperawatan pasien.

Cara analisis data adalah:

(1) Validasi data, meneliti kembali data yang terkumpul.

(2) Mengelompokkan data berdasarkan kebutuhan biopsiko-sosial dan spiritual.

(3) Membandingkan dengan standar.

(4) Membuat kesimpulan tentang kesenjangan yang ditemukan.

b) Interpretasi data 
(1) Menentukan kelebihan pasien. Jika pasien memenuhi standar kriteria kesehatan, perawat akan menyimpulkan bahwa pasien memiliki kelebihan dalam hal tertentu dan kelebihan ini dapat digunakan untuk membantu menyelesaikan permasalahan pasien.

(2) Menentukan masalah pasien/ menyimpulkan.

Jika pasien tidak memenuhi standar kriteria kesehatan maka pasien tersebut mengalami keterbatasan dalam aspek kesehatannya dan memerlukan pertolongan.

(3) Menentukan masalah pasien yang pernah dialami, tahap ini perawat menentukan masalah potensial pasien.

(4) Penentuan keputusan.

(a) Tidak ada masalah tetapi perlu peningkatan status dan fungsi (kesejahteraan) : tidak ada indikasi respon perawat, meningkatnya status kesehatan, adanya inisiatif promosi kesehatan.

(b) Masalah kemungkinan. Pola mengumpulkan data untuk memastikan ada atau tidaknya masalah yang diduga.

(c) Masalah aktual atau risiko. Pasien tidak mampu merawat karena pasien menolak masalah dan pengobatan.

(d) Masalah kolaboratif. Konsultasikan dengan tenaga kesehatan profesional yang kompeten dan bekerja secara kolaboratif pada masalah tersebut.

c) Validasi data Pada tahap ini perawat memvalidasi data yang ada secara akurat yang dilakukan bersama pasien dan keluarga atau masyarakat. Validasi ini dilaksanakan dengan mengajukan pertanyaan yang reflekif kepada pasien atau keluarga tentang kejelasan interpretasi data.

d) Merumuskan diagnosa keperawatan Perumusan diagnosa keperawatan didasarkan pada identifikasi masalah dan

kemungkinan penyebab. Selain itu perumusan diagnosa juga sesuai dengan kebutuhan pasien.

\section{5) Tipe diagnosa keperawatan}


Tipe diagnosa keperawatan menurut Carpenito (2009) sebagai berikut:

a) Diagnosa keperawatan aktual.

Diagnosa keperawatan aktual adalah diagnosa menjelaskan masalah yang nyata terjadi saat ini. Pada diagnosa keperawatan aktual batasan karakteristiknya adalah tanda dan gejala yang bila terlihat dalam waktu yang sama mewakili diagnosa keperawatan. Batasan karakteristik dibedakan menjadi karakteristik mayor dan minor. Mayor setidaknya satu tanda harus ada untuk validasi diagnosa, minor mendukung bukti tetapi boleh tidak ada.

b) Diagnosa keperawatan risiko.

Diagnosa keperawatan risiko adalah keputusan klinis yang divalidasi oleh faktor risiko. Tidak terdapat tanda dan gejala mayor.

c) Diagnosa keperawatan potensial.

Diagnosa keperawatan potensial adalah diagnosa yang didasarkan atas kondisi sehat klien untuk mencapai tingkat kesehatan yang lebih tinggi.

d) Diagnosa keperawatan kemungkinan.

Diagnosa keperawatan kemungkinan adalah pernyataan tentang masalah yang diduga akan terjadi, masih memerlukan data tambahan.

e) Diagnosa keperawatan sindroma

Diagnosa keperawatan sindroma adalah sekelompok atau kumpulan dari beberapa diagnosa keperawatan yang terjadi secara bersamaan yang memiliki penyebab tunggal. Berdasarkan peraturan menteri kesehatan Republik Indonesia nomor 40 tahun 2017 menyatakan bahwa salah satu kompetensi perawat adalah merumuskan diagnosa keperawatan.

\section{B. KEPUASAN PASIEN}

\section{1) Definisi kepuasan pasien}

Kepuasan pasien merupakan respon atau tingkat perasaan pasien yang diperoleh setelah pasien menerima jasa pelayanan keperawatan di rumah sakit dengan membandingkan antara kinerja atau hasil yang dirasakan dengan harapan pasien. Apabila hasil yang dirasakan 
dibawah harapan maka pasien akan kecewa, kurang puas bahkan tidak puas, namun sebaliknya bila sesuai dengan harapan, pasien akan puas dan bila kinerja melebihi harapan maka pasien akan sangat puas.Kepuasan yang terjadi pada pasien karena harapan-harapan yang ada pada diri pasien terpenuhi. Kepuasan merupakan gambaran harapan pasien yang terpenuhi dalam menggunakan jasa rumah sakit.

Kepuasan pasien merupakan perasaan yang dimiliki pasien dan timbul sebagai hasil dari kinerja layanan kesehatan setelah pasien membandingkannya dengan apa yang diharapkan (Pohan, 2007). Hasil tersebut berupa respon dari pasien terhadap pelayanan kesehatan yang diterima secara nyata. Pelayanan kesehatan yang dimaksud dalam penelitian ini yakni pelayanan keperawatan. Pelayanan keperawatan yang diterima oleh pasien ternyata lebih buruk dari harapan pasien, maka pasien tersebut merasa tidak puas karena merasa kecewa. Apabila pelayanan keperawatan yang diterima oleh pasien ternyata sebanding dengan harapan pasien maka pasien merasa puas (senang). Kepuasan pasien adalah suatu prioritas yang akan membantu perawat dalam memberikan pelayanan keperawatan agar pasien mau berparisipasi selama perawatan.

Menurut Kotler dan Keller (2009), kepuasan pelanggan (customer satisfaction) diartikan sebagai fungsi dari seberapa sesuainya harapan pembeli produk dengan kinerja yang dipikirkan pembeli atas produk tersebut. Westbrook dan Reilly juga memberikan definisi atau pengertian kepuasan pelanggan (customer satisfaction) sebagai respons emosional terhadap pengalamanpengalaman berkaitan dengan produk atau jasa tertentu yang dibeli, gerai ritel, atau bahkan pola perilaku (seperti perilaku berbelanja dan perilaku pembeli), serta pasar secara keseluruhan (dalam Tjiptono 2008).

\section{2) Tingkat kepuasan pasien}

Menurut Gerson (2002), untuk mengetahui tingkat kepuasan pasien dapat diklasifikasikan dalam beberapa tingkatan sebagai berikut :

\section{Sangat memuaskan}

Diartikan sebagai ukuran subjektif hasil penilaian perasaan pasien yang menggambarkan pelayanan kesehatan sepenuhnya atau sebagian besar sesuai kebutuhan atau keinginan pasien, seperti sangat bersih (untuk prasarana), sangat ramah (untuk hubungan dengan dokter atau perawat), atau sangat cepat (untuk proses 
administrasi), yang seluruhnya menggambarkan tingkat kualitas pelayanan yang paling tinggi.

2. Memuaskan

Diartikan sebagai ukuran subjektif hasil penilaian perasaan pasien, yang menggambarkan pelayanan kesehatan tidak sepenuhnya atau sebagian sesuai kebutuhan atau keinginan seperti tidak terlalu bersih (untuk sarana), agak kurang cepat (proses administrasi), atau kurang ramah, yang seluruhnya ini menggambarkan tingkat kualitas yang kategori sedang.

3. Tidak memuaskan

Diartikan sebagai ukuran subjektif hasil penilaian perasaan pasien rendah, yang menggambarkan pelayanan kesehatan tidak sesuai kebutuhan atau keinginan seperti tidak terlalu bersih (untuk sarana), agak lambat (untuk proses administrasi), atau tidak ramah.

4. Sangat tidak memuaskan.

Diartikan sebagai ukuran subjektif hasil penilaian perasaan pasien yang rendah, menggambarkan pelayanan kesehatan tidak sesuai kebutuhan atau keinginan seperti tidak bersih (untuk sarana), lambat (untuk proses administrasi), dan tidak ramah. Seluruh hal ini menggambarkan tingkat kualitas yang kategori paling rendah.

Mutu pelayanan keperawatan dikatakan baik jika pihak rumah sakit memberikan pelayanan yang setara dengan yang diharapkan oleh pasien atas kebutuhan pasien. Sedangkan mutu disebut buruk jika pasien memperoleh pelayanan keperawatan yang kurang sesuai dengan kebutuhan dan harapan pasien. Pelayanan terbaik pada pasien dan tingkat kualitas dapat dicapai secara konsisten dengan memperbaiki pelayanan dan memberikan perhatian khusus pada standar pelayanan keperawatan yang telah ditetapkan oleh pihak rumah sakit.

Berdasarkan literatur yang saya baca, berdasarkan penelitian dari jurnal Fatmawati Astar, Hasmin Tamsah, Ikhasan Kadir, yang berjudul "PENGARUH PELAYANAN ASUHAN KEPERAWATAN TERHADAP KEPUASAN PASIEN DI PUSKESMAS TAKALALA KABUPATEN SOPPENG” yang bertujuan untuk mengetahui pengaruh pelayanan suhan keperawatan terhadap kepuasan pasien di puskesmas takalala kabupaten soppeng berisikan dari hasil uji t anova didapatkan hasil diagnosa berpengaruh negatif dan 
signifikan terhadap kepuasan pasien, hal ini terlihat dari nilai t hitung untuk variabel Diagnosa (X2) lebih besar dari t tabel, yakni (-) 2,175 > 1,711 dan nilai signifikansi lebih besar dari 0,05 yakni 0,040.

Dari jurnal tersebut berarti bahwa semakin lengkap, akurat dan jelas penjelasan tentang diagnosa keperawatan maka kepuasan pasien akan semakin menurun. Hal ini disebabkan karena diagnosa keperawatan/ masalah kesehatan merupakan salah satu stressor pasien. Dari data hasil jawaban rata-rata responden didapatkan secara umum, tingkat diagnosa keperawatan berada pada level sangat tinggi. Hal ini terlihat pada indikator pertama yaitu actual, memiliki rata-rata jawaban responden yakni sebesar 4.00 yang masuk pada kategori tinggi (antara 3.01 -4.00). kemudian pada ada indikator kedua yaitu risiko atau resiko tinggi, memiliki rata-rata jawaban responden yakni sebesar 3,97 yang masuk pada kategori tinggi (antara 3.01 - 4.00). Selanjutnya pada indikator ketiga yaitu kemungkinan, memiliki rata-rata jawaban responden yakni sebesar 4,03 yang masuk pada kategori sangat tinggi (antara 4.01 - 5.00). Pada indikator keempat yaitu sejahtera, memiliki rata-rata jawaban responden yakni sebesar 4,07 yang masuk pada kategori sangat tinggi (antara 4.01 5.00). dan terakhir pada indikator kelima yaitu syndrome, memiliki rata-rata jawaban responden pada indikator kelima yakni sebesar 4.00 yang masuk pada kategori tinggi (antara $3.01-4.00)$.

\section{PENUTUP}

Kepuasan pasien sangat dipengaruhi oleh sikap dan pendekatan perawat di rumah sakit kepada pasien, mutu pelayanan keperawatan yang diterima pasien. Kepuasan pasien memiliki pengaruh yang signifikan terhadap pembelian layanan ulang kesehatan atau pasien akan kembali lagi berkunjung ke rumah sakit. Pasien yang tidak puas dapat berpindah ke fasilitas layanan kesehatan lain dan kurang berkerja sama dalam perawatan dan pengobatan. Dalam beberapa referensi jurnal yang saya baca, saya menemukan bahwa terdapat pengaruh positif dan signifikan Diagnosis keperawatan terhadap kepuasan pasien. Berdasarkan salah satu jurnal yang saya baca mengatakan bahwa semakin lengkap, akurat dan jelas penjelasan tentang diagnosa keperawatan maka kepuasan pasien akan semakin menurun. Hal ini disebabkan karena diagnosa keperawatan/ masalah kesehatan merupakan salah satu stressor pasien. 


\section{DAFTAR PUSTAKA}

1. Apriyani, Heni. (2015). Identifikasi Diagnosis Keperawatan Pada Pasien Di Ruang Paru Sebuah Rumah Sakit. Jurnal Keperawatan Volume XI, No. 1

2. Asmadi. (2005). Konsep Dasar Keperawatan. Jakarta : Penerbit Buku Kedokteran EGC

3. Astar, Fatmawati., Tamsah, Hasmin., \& Kadir, Ikhasan. (2014). Pengaruh Pelayanan Asuhan Keperawatan Terhadap Kepuasan Pasien Di Puskesmas Takalala Kabupaten Soppen. mirai : journal of management vol. 1 no. 2

4. Budiono. (2016). Konsep Dasar Keperawatan. Jakarta : Kementrian Kesehatan Republik Indonesia

5. Efendi, Ferry., \& Makhfudli. Keperawatan kesehatan komunitas : Teori dan praktik dalam keperawatan. Jakarta : Penerbit salemba medika

6. Efendi, Rustam., Arifin, Alwy., \& Darmawansyah. (2014). Hubungan Mutu Pelayanan kesehatan dengan kepuasan pasien rawat jalan di puskesmas aeng towa kabupaten takalar

7. Mulyati., Susanti, Eri., Aryati, Septiyani., Mardhotillah, Elly., maftukhah., Sulistyowati, Gati., Indrayati, Novi., \& PH, Livana. (2020) . Tingkat kepuasan pasien dalam menerima pelayanan asuhan keperawatan. Jurnal keperawatan volume $12 \mathrm{No}$ 1 Hal 57-62

8. Simamora, R. H., Bukit, E., Purba, J. M., \& Siahaan, J. (2017). Penguatan kinerja perawat dalam pemberian asuhan keperawatan melalui pelatihan tonde keperawatan di rumah sakit royal prima medan. Jurnal pengabdian kepada masyarakat, 23 (2), 300-304

9. Sunaryo. (2015). Asuhan Keperawatan Gerontik. Jakarta : CV Andi Offset

10. Widiasari., Handiyani, Hanny., \& Novieastari, Enie. (2019). Kepuasan Pasien Terhadap Penerapan Keselamatan Pasien Di Rumah Sakit. Jurnal Keperawatan Indonesia, 2019, 22 (1), 43-52

11. Wulandini, Putri., Krianto, Tri., \& Priwahyuni, Yuyun. (2016). Faktor-Faktor Yang Berhubungan Dengan Pendokumentasian Asuhan Keperawatan Di Rumah Sakit Jiwa. ners jurnal keperawatan, Volume 12, No.2 